\title{
Reviewing Effective Factors of Alimentary Deficiency in Animals Reproductive Functions
}

\author{
Pavlo Skliarov $^{1 *}$, Serhiy Fedorenko ${ }^{2}$, Svitlana Naumenko², Oleksandr Onyshchenko ${ }^{2}$, Alina Pasternak ${ }^{2}$, Liliya \\ Roman $^{3}$, Maryna Lieshchova ${ }^{3}$, Dmytro Bilyi ${ }^{1}$, and Olga Bobrytska ${ }^{2}$ \\ ${ }^{1}$ Department of Surgery and Obstetrics of Farm Animals, Faculty of Veterinary Medicine, Dnipro State Agrarian and Economics University, Serhii Efremov Str., 25, \\ Dnipro, 49600, Ukraine \\ ${ }^{2}$ Department of Veterinary Reproductology, Faculty of Veterinary Medicine, Kharkiv State Zooveterinary Academy, Academichna Str., 1, vil. Mala Danylivka, Dergachi \\ distr., Kharkiv reg., 62341, Ukraine \\ ${ }^{3}$ Department of Surgery, Obstetrics and Small Animal Diseases, Faculty of Veterinary Medicine and Biotechnology, Odesa State Agrarian University, Panteleymonovskaya \\ Str., 13, Odesa, 65012, Ukraine \\ *Corresponding author's Email: skliarov.p.m@dsau.dp.ua; (DORCID: 0000-0002-4379-9583
}

\begin{abstract}
Animal reproduction is one of the main factors limiting the efficiency of livestock production. Its optimal level is possibly achieved when certain conditions are created for animals. As reproduction is a complex reflex process depending on neuroendocrine regulatory mechanisms, the character and strength of stimuli, which, in turn, is due to a number of factors. Under normal conditions, the body of animals is affected by many different factors, which are appropriately transformed and specified by positive or negative reactions. Inhibitory factors include air pool, saturated with harmful substances and gases, ionizing radiation, poor water quality along with altered redox properties, hypokinesia combined with poor unbalanced feeding, systematic chronic stress, presence of toxic substances in feed, and the deficiency of vitamins and other bioantioxidants in feed or their excessive spending. Of the wide range of genetic and paratypic factors of negative impacts on reproductive capacity, the most common one is alimentary, which causes impaired reproductive function due to deficiencies in the rules, regulations, and feeding regime of animals. In particular, the alimentary can be associated with both general malnutrition (starvation) and overfeeding (obesity). However, the alimentary form of infertility mostly occurs due to low-quality diets when the diet lacks vital components (mainly vitamins, macro-, and micronutrients) or the quantitative ratios of the ingredients are violated. This is possible even if the total nutritional value of the diet meets the established requirements for the physiological needs of the body. Vitamins, micro-, and macronutrients are ecologically deficient factors of disturbance of animal reproductive function, the influence of which is observed on all processes of reproduction, from fertilization to the postpartum period and the preservation of young animals. The pathogenesis of their insufficiency is associated with the violation of steroido-, gameto-, and embryogenesis and the emergence of ante-, intra-, neo- and postnatal pathologies, respectively. Therefore, treatments and prevention measures should be aimed at providing animals with biologically complete balanced feeding and replenishment of the body with vitamins and minerals. However, all these issues remain incompletely studied and need further research.
\end{abstract}

Keywords: Alimentary deficiency, Animals, Reproductive function.

\section{INTRODUCTION}

The optimal level of procreation is possible only if certain conditions are created for animals because reproduction is an extremely important function with a complex reflex process that depends on neuroendocrine regulatory mechanisms and the character and strength of stimuli acting on the body (Koshovyj, 2004; Iolchiev et al., 2014; Kagermazov and Taov, 2018). Under normal conditions, the body of animals is affected by many different factors, which are appropriately transformed and manifested by positive or negative reactions. Inhibitory factors include air pool saturated with harmful substances and gases, ionizing radiation, poor water quality along with altered redox properties, hypokinesia combined with poor and unbalanced feeding, systematic chronic stress, presence of toxic substances in feed, and the deficiency of vitamins and other bioantioxidants in feed or their excessive spending (Skljarov, 2017).

Currently, there is a rapid development of important sections of veterinary science, including vitaminology and microelementology, as the main areas in the study of etiopathogenesis, as well as structural and functional changes in the organs of alimentary-deficient nutrition. This also applies to veterinary reproductive medicine, in particular, perinatology, mammology, gynecology, and andrology (Beleckaja and Onul, 2014; Skljarov and Koshevoj, 2016).

\section{RESULTS AND DISCUSSION}

Of the wide range of genetic and paratypic factors of negative impacts on reproductive capacity, the most common one is alimentary, which causes reproductive dysfunction due to deficiencies in norms, rules, and feeding regimes (Bindari et 
al., 2013; Amin, 2014; Ibtisham et al., 2018). In particular, it can be associated with both general malnutrition (starvation) and overfeeding (obesity). However, the alimentary form of infertility commonly occurs based on lowquality diets, which means when the diet lacks vital components (mainly vitamins, macro- and micronutrients), or the quantitative ratio among them is disturbed (Mahan and Vallet, 1997; Hovdenak and Haram, 2012; Omur et al., 2016). This is possible even if the total nutritional value of the diet meets the established requirements for the physiological needs of the organism (Vizner, 1976; Perevozchikov et al., 2014).

The most sensitive animals to high-quality defective feeding are the heifers and highly productive animals, especially in the winter-spring period of stall keeping. The absence or lack of vitamins and minerals in the diet, even with satisfactory fattening of animals, can cause violation of sexual cyclicity, disorders of fertilization and implantation, various pathologies of pregnancy, labor, and the postpartum period (Pasynkova, 2013; Shatohin et al., 2017).

These disorders have a wide range, which can be temporary or permanent, and affect all aspects of the reproductive process, including morphological and functional state of the self-regulatory system (hypothalamus, pituitary, gonads, uterus), readiness and ability to develop an egg cell from maturing to physiologically determined follicles, ability and readiness for fertilization. Which is possible during regular sexual cycles without violating the internal and external signs of their manifestation; absence of disorders of implantation (nidation) of the embryo in the mucous membrane of the uterus; functioning of the fetoplacental complex, fetal development, pregnancy, childbirth; the birth of a full-fledged offspring, which itself, after directed growth, can reach sexual maturity promptly; the course of the postpartum period; and timing and fullness of the manifestation of sexual hunting after childbirth (Koshovyj, 2004; Skliarov et al., 2020 a).

\section{Vitamins}

Vitamins are one of the most important factors influencing sexual function. Vitamins are substances of high biological activity that are involved in all vital processes (for example, metabolic processes, immunity, hormonal genesis and others) in the body. To date, more than 20 vitamins and vitamin-like substances have been studied, the deficiency or absence of which leads to disorders in the body. Although animals need small quantities of vitamins, their constant lack in the diet can lead to metabolic disorders, specific diseases, reduced productivity and product quality, as well as impaired reproducibility (Plemjashov, 2010; Matte and Lauridsen, 2013). Vitamins play both direct and indirect roles in the process of reproduction, especially endocrine and genital systems. Histochemistry has shown an increase in the content of some vitamins in many endocrine organs. From this, it can be concluded that the organs associated with the reproductive system need more of these vitamins (Vizner, 1976).

Not only the amount but also the ratio of vitamins entering the body is important for reproduction. The vitamin requirements depend on the composition of feed, animal productivity, and depot of vitamins in the body, moreover, vitamin requirements increase with pathological conditions and the use of drugs (antibiotics and sulfonamides) (Sidorkin et al., 2007; Savinova et al., 2015). Hypovitaminosis is more often reported in some animals due to vitamin deficiency in the diet or mineral imbalance in the feed affecting their metabolism and absorption (Umahanov, 2017).

\section{Fat-soluble vitamins}

Vitamin A (retinol) is the most important component for the functioning of the reproductive system, compared to other vitamins. Therefore, retinol is rightly called the vitamin of reproduction (Hurley and Doane, 1989; Koshovyj, 2004). In recent years, the causes of insufficient supply of Vitamin A in animals and prevention measurements have grown into a problem that is of paramount importance in herd reproduction. This issue became critical especially during the winter stall keeping of animals because the precursor of retinol is carotene, which is easily destroyed by environmental factors, such as temperature and humidity (Hurley and Doane, 1989; Blaner et al., 2016; Kuz'minova et al., 2017). Vitamin A is important in maintaining the body's resistance to adverse external and internal factors, ensuring the normal state of the epithelium of the genital mucosa, follicular epithelium of the ovary, and secretory activity of the uterine glands. Retinol is required for the formation of steroid and pituitary hormones, and also plays an important role in cell differentiation during embryogenesis, and in particular the formation of the fetal immune system (Skliarov et al., 2020b). Its deficiency causes disorders in spermatogenesis. In fact, sexual cycles are defective, implantation is disrupted, embryonic mortality occurs, pregnancy, childbirth, and the postpartum period are complicated, and the offspring is not very viable (Hogarth and Griswold, 2010; Gromova et al., 2019; Maia et al., 2019).

Vitamins of group D are active regulators of phosphorus calcium metabolism, providing their normal ratio in the blood of animals (Bourdeau et al., 1986). Vitamin D deficiency is usually observed during the winter when it is difficult to walk and isolate animals. Vitamin D becomes important for reproduction when the level of calcium and phosphorus supply deviates significantly from the optimal rate (Brommage et al., 1990).

Information addressing the specific effects of Vitamin D on reproductive function is limited (Hurley and Doane, 1989). It is known that the level of reproduction depends on the provision of the body with Vitamin D (Luk et al., 2012). As Gromova et al. (2017) mentioned, Vitamin D levels have a direct effect on the genitals, and an indirect effect on stimulation of the synthesis of steroid hormones (estrogen, progesterone, testosterone) in both males and females. 
Moreover, there are convincing data on the effect of Vitamin D on many gynecological diseases (Kalinchenko et al., 2016). Expressed D-hypovitaminosis in animals during the active growth period inhibits the development of the genitals (Vizner, 1976), and also affects the physiology of the ovary (Irani and Merhi, 2014).

In all these cases, the inclusion of Vitamin D in the diet or its use in doses that would meet the needs of the body can prevent possible disorders of the reproductive capacity of animals to some extent, including the duration of the placenta, the period from calving to first insemination, and fertilization index (Hurley and Doane, 1989; Umahanov, 2017).

Vitamin $\mathrm{E}$ is found in almost all tissues, but especially in the uterus, testicles, adrenal glands, and pituitary gland, it is much more than in other organs indicating the specificity of the functions of this vitamin in these organs (Vizner, 1976; Koshovyj, 2004). Vitamin E acts in the body as an antioxidant regulating the body's absorption of Vitamin A, and fat metabolism (Hurley and Doane, 1989). In addition, it affects the activity of the anterior pituitary gland and stimulates the production of gonadotropins (Vizner, 1976).

With E-hypovitaminosis in pregnant females, toxic products of fat metabolism are accumulated, which are harmful to the embryo. Accordingly, the incidence of embryonic mortality, stillbirths, and non-viable fetuses are increased (Vizner, 1976). In males, there are degenerative processes in sperm, epithelium of seminiferous tubules, reduced sexual activity, and also various pathologies of adnexal gonads can arise (Evans and Bishop, 1922; Gullickson et al., 1949; Hurley and Doane, 1989). In experiments on pigs, an increase in the size of the placenta and a decrease in the mortality of piglets with the use of Vitamin E have been described, but this positive result remained unclear (Pinelli-Saavedra, 2003).

Regarding Vitamin K, there are few reports of the effects of Vitamin K on the reproductive functions in animals (Potter, 1945; Metta and Johnson, 1960; Jacob et al., 2012). Thus, studies on rodents have reported that the concentration of Vitamin K in the ovaries was higher than other organs, indicating its role in female reproduction (Huber et al., 1999). Moore et al. (1942) described the cases of abortion in rabbits fed a diet deficient in Vitamin K. Vizner (1976), citing data from Italian authors, pointed to the positive effect of Vitamin $\mathrm{K}$ on the reproductive capacity, which is thought to be due to its stimulation of the production of anterior pituitary hormones. Vitamin K deficiency in breeding chickens can cause increased embryonic mortality. However, both of these provisions are controversial. New roles of Vitamin $\mathrm{K}$ have been studied, including the role of estrogen in its metabolism, which requires further research (Truong and Booth, 2011). Baldoceda-Baldeon et al. (2014) found a positive effect of Vitamin K on the embryonic development of cattle in vitro, particularly its addition contributed to the improvement of their morphological quality.

\section{Water soluble vitamins}

Vitamins of group B takes an active part as coenzymes in many enzymatic processes, its deficiency inhibits specific metabolic processes. Their deficiency reveals significant disorders of reproductive function, which is consistent with the well-known theory of the participation of enzymes in the process of reproduction (Vizner, 1976). All types of Vitamins of group B are essential for fetal growth and development, and their deficiency causes abortion (Lewis and Everson, 1952; Hurley and Doane, 1989).

Hertz (1946) reported the effect of Vitamin B on endocrinological aspects of reproduction. Although Vitamin B deficiency can affect the reproductive capacity in animals, it is less potent than other vitamins. As the lack of other vitamins, B-avitaminosis or hypovitaminosis B in practice may be relevant only for pigs and domestic fowl since they are synthesized in the forestomach of ruminants. The uncontrolled use of antibiotics can lead to Vitamin B deficiency in ruminants.

In severe cases, thiamine deficiency leads to impaired development of the embryonic epithelium and reduced fertility. In roosters, there is an inhibition of testicular development and degeneration, and in chickens, it leads to ovarian atrophy. In pigs, premature births, high infant mortality, and increased ugliness can be observed (Vizner, 1976).

Dysfunction of reproduction due to lack of riboflavin is described mainly in pigs and domestic fowl. In sows, there may be a decrease in fertility as well as infertility due to the resorption of embryos or fetal death and the birth of lowviability piglets. Skeletal anomalies in the fetus were also reported (shortening of various bones and fusion of ribs). In the hens, egg-laying was disturbed, incubation qualities of eggs was deteriorated especially in the second week of incubation (period of high embryonic activity), low-viability dwarf chickens hatched with widespread edema and characteristic down curl leading to a high mortality rate at an early age (Vizner, 1976).

The mere violation of the synthesis of sterols and steroids due to the lack of pantothenic acid indicated its connection with the processes of reproduction. Young pigs with pantothenic acid deficiency are useless due to underdevelopment of the genitals or atrophy and inactivity of the ovaries. Adult females pigs are normally fertilized, but the fetuses often die. Infertility occurs due to the resorption of embryos, and later the loss of lactation. Piglets are born dead, underdeveloped, or poorly viable. In poultry, a decrease in the content of pantothenic acid in eggs due to its lack in the diet is associated with a decrease in hatchability. Chickens are unable to hatch from their own eggs and remain in the shell. Egg-laying is also disturbed (Vizner, 1976). 
Sows that do not receive or receive little choline from feed, give birth to low-viability piglets, most of which have gonadal abnormalities and low live weight before weaning. Regarding breeding chickens and laying hens, reduced egg production, often the expulsion of some yolks and increased mortality of chickens were often observed (Vizner, 1976). Vitamin $\mathrm{B}_{12}$ deficiency is associated with adverse effects on mothers and newborns, including developmental abnormalities, miscarriages, preeclampsia, and low birth weight (Reznikoff-Etiévant et al., 2002; Finkelstein et al., 2015).

In the absence of cyanocobalamin, pigs and domestic fowl are particularly affected by reproductive disorders, in which their own synthesis of Vitamin $B_{12}$ does not meet the requirements. At the same time, Vitamin $B_{12}$ supplements can reduce embryonic mortality, and increase the vitality of newborn piglets. In domestic fowl with Vitamin $\mathrm{B}_{12}$ deficiency, egg production was disturbed with a decrease in the incubation qualities of eggs, and there was a report of increased embryonic and post-embryonic mortality as well as a decrease in the ability to hatch (Luck et al., 1995). Hatched chickens had partial disorders in bone development. Instead, ruminants with sufficient intake of cobalt in the feed do not need Vitamin $B_{12}$ supplements due to their ability to synthesize it in the required amount (Vizner, 1976).

Vitamin $\mathrm{C}$ (ascorbic acid) is an active stimulant of metabolism, participates in blood clotting, stimulates the phagocytic activity of leukocytes, reticulocyte system, and the formation of antibodies, and increases the body's defenses against infection (Hurley and Doane, 1989). Ascorbic acid is found in all tissues of the body, but in the pituitary gland, adrenal glands, and ovaries, it is much more than in the blood. This suggests that Vitamin $\mathrm{C}$ is required for the functioning of these incretory glands associated with animal reproduction. Ascorbic acid has long been associated with fertility, but any consistent study of the mechanism of its action on the reproductive organs has not been conducted (Briggs, 1973; Millar, 1992).

Three main functions of ascorbic acid that may explain its reproductive effects are considered, namely its promotion of collagen synthesis, its role in hormone production, and its ability to protect cells from free radicals. It can be concluded that ascorbic acid is a key compound in the physiology of the gonads, which requires further research, and that a reassessment of its potential clinical significance in the treatment of various types of male and female infertility will be timely (Luck et al., 1995). It is believed low blood ascorbic acid can lead to some functional disorders in the genitals of cows, especially the ovaries. Although some researchers claim that Vitamin $\mathrm{C}$ supplements can increase the fertility of ruminants, there is no experimental evidence (Koshovyj, 2004). Other reports have indicated the effects of ascorbic acid on gonadotropic hormone activity (Di Cio and Schteingart, 1942) and male fertility (Dawson et al., 1990). With a normal supply of Vitamin $\mathrm{C}$ to the body, a positive effect on the activity of gonadotropic hormones and male fertility is expected. In the case of insufficiency, these processes reduce their activity.

Ascorbic acid is one of the vitamins of the so-called antioxidant complex, similar to Vitamins A and E. With such a combined vitamin deficiency, it disrupts not only sexual cycling but also the emerging dysbiotic processes in the biotopes of the reproductive tract, which are known to be predictors of inflammatory diseases of the internal genitals, and can threaten the loss of reproductive function (Golovanova and Strokova, 2011). In this regard, there are reports of beneficial effects of parenterally administered ascorbic acid in various forms of infertility in cattle. Thus, the introduction of this vitamin 1-2 times a week at a dosage of 1-2 g per $500 \mathrm{~kg}$ of live weight could increase the sexual activity of young bulls. In the pituitary gland, adrenal glands, as well as in the testicles and ovaries, Vitamin $\mathrm{C}$ is much more than in the circulating blood. The content of Vitamin $\mathrm{C}$ in semen clearly correlates with its quality. Its presence in the above endocrine glands leads to the conclusion that ascorbic acid is necessary for the normal functioning of the most important incretory organs associated with the reproductive system (Vizner, 1976).

Although all vitamins affect reproduction, Vitamins A, D, and E usually play a dominant role. Thus, the use of vitamin supplements in the dry and postpartum periods of cows had a positive effect on their reproductive function and viability of obtained calves. Administration of Vitamin A, trivitamin, or tetravit oil for dry cows in the second half of the winter stall period significantly reduced the number of postpartum diseases, shortened the period of placenta separation, increased the fertility from the first insemination, contributed to the reduction of early embryonic mortality, reduced the service periods and the periods between calving, and reduced the percentage of the diseases in newborn calves (Manalili and Bernardo, 1996; Weiss, 1998).

Research by Umahanov (2017) indicated the possibility of preventing early embryonic losses and improving the results of insemination of cows by injection of Vitamins A, D, and E in the first days after calving. Adding a complex of mentioned fat-soluble vitamins to the feed for 1.5-2 months before calving and one to two months after calving provided a reduction in the incidence of placental retention and the occurrence of postpartum genital diseases, accelerated the onset of hunting, increased the effectiveness of insemination of cows, reduced the period between calving, and sharply decreased the morbidity rate of calves.

\section{Minerals}

The influence of minerals (macro- and microelements) on metabolic processes can be judged from the consequences that arise from insufficient or excessive intake by animals. These effects are multifaceted and 
characterized by varying degrees of intensity (Christian, 2003). Among them, it is necessary to allocate the disturbance of reproductive ability of animals, reduced viability of newborns, dysfunction of organs and systems and the occurrence of nutritional diseases, reduced animal productivity, insufficiently nutrient diets, and increased feed costs for product formation (Bohstedt, 1942; Malysheva, 2007).

Animals are in need of minerals. In addition to sufficient intake, their certain ratio among themselves is also required. The value of individual inorganic substances for reproduction varies, but most of them are clearly defined. Usually the lack of not one, but several elements is registered (Vizner, 1976; Ramakrishnan et al., 1999; Christian, 2003).

About 70 chemical elements were found in the tissues and organs of animals. Minerals according to Koshovyj (2004), made 4-6\% of the live weight of animals. Calcium and phosphorus are so closely associated with a metabolism, and have many common interactions that need to be considered in conjunction (Ruan et al., 2007). In addition, the symptoms of calcium deficiency are partially similar to the symptoms of phosphorus deficiency (Vizner, 1976). To date, there is no evidence that calcium and phosphorus imbalances have a significant effect on reproductive function, but at the same time, changes in the $\mathrm{Ca} / \mathrm{P}$ ratio may affect ovarian function (Yasothai, 2014).

If the reserves of calcium and phosphorus are scarce or already depleted, the activity of the gonads is disrupted, as the breast has an advantage in the order to supply minerals. This causes violations of the sexual cycle and fertilization, due to which the period between calving is prolonged, and the animal remains temporarily infertile. The period of rest of sexual functions is maintained until the lack of minerals is compensated, accordingly, the conditions for the physiological course of sexual functions for fertilization and subsequent formation of the zygote in the uterus will not be created. Another situation is observed until the end of lactation. When milk production decreases and the body's mineral balance is restored by consuming foods with adequate calcium and phosphorus, the required amounts of these elements are used to, and thus, re-create the conditions for normal sexual activity (Vizner, 1976).

The decrease in reproductive capacity observed in phosphorus deficiency should be considered as a consequence of general metabolic disorders, especially lack of energy, as acquired by the neuroendocrine system, the syndrome of adaptation to poor feeding conditions. Thus, phosphorus deficiency significantly reduces the body's resistance to infectious diseases, fatness, feed intake, and the ability to transform carotene into Vitamin A, which can cause infertility (Vizner, 1976). Calcium and phosphorus deficiency or their impaired ratio leads to anaphrodisia or defective sexual cycles and other reproductive disorders (Hurley and Doane, 1989; Seyfi et al., 2005; Ruginosu et al., 2011). Their connection with Vitamin D is especially important for reproductive processes (Vizner, 1976; Sun et al., 2015).

Although none of the mineral elements has a strictly specific effect on the function of reproduction, phosphorus, based on its outstanding role in the intermediate metabolism, is still effective in the reproduction process. When comparing the mineral status of an animal with normal and reduced reproductive capacity, phosphorus deficiency is always found in the diets of the latter (Koshovyj, 2004). It has been reported that low phosphorus consumption caused a decrease in ovarian function, delayed puberty, and low fertility rates (Yasothai, 2014).

During sexual hunting and heat in the midbrain, pituitary gland, and ovaries, the organs that control sexual function and phosphate metabolism increase (Hurley et al., 1982; Tallam et al., 2005). Sperm also has a lot of phosphoruscontaining proteins. The assumption of the existence of diseases associated with phosphorus deficiency is made. In particular, the connection between phosphorus deficiency and cattle disease, accompanied by ataxia, spastic paralysis, and severe reproductive disorders was noted by Vizner (1976).

Vizner (1976) summarized the results and generalizes the negative impact of phosphorus deficiency in cows on the manifestations of their reproductive capacity after a general analysis of literature reports. Infertility caused by phosphorus deficiency can be eliminated by providing the body with this element - with food or by introducing phosphorus-containing drugs (Koshovyj, 2004).

However, some other observations and research results have indicated that reducing the amount of feed by $30 \%$ leads to a sharp decline in reproductive capacity in the absence of a difference in the level of phosphorus (Vizner, 1976). Pregnant were those animals that later died from phosphorus deficiency or showed clinically pronounced bone changes. Prolonged keeping of animals on deficient diets for phosphorus has led to a marked inhibition of their development and growth, but the rhythm of sexual cycles has not changed. The study of the uterus and ovaries, conducted after the experiments, has not indicated an adverse effect of phosphorus deficiency on genital function. This indicates an indirect relationship between phosphorus levels and reproductive dysfunction.

Calcium is essential in mammalian breeding conditions (Baczyk et al., 2011; Correia et al., 2015; Kornbluth and Fissore, 2015). First, it promotes critical processes of individual development, such as skeletal formation and mineralization, lungs, kidneys, and neural circuits (Leclerc et al., 2011; Riccardi et al., 2013; Kovacs, 2015). Similar to phosphorus, this mineral is most often associated with reduced fertility in highly productive dairy cows. Calcium violation (deficiency) is usually common during childbirth or for several days after it. Negative calcium balance in the first third of lactation often occurs due to the use of its reserve during pregnancy. This can cause a sharp decrease in serum calcium, which will create conditions for postpartum paresis (Yasothai, 2014). Catt et al. (1985) found that the 
processes of activation of gonadotropin secretion receptors strongly depend on the level of calcium supply. The connection between the level of calcium metabolism and reproduction in poultry was revealed (Simkiss, 1961; Luck and Scanes, 1979). Vizner (1976) concluded that some forms of infertility in cows can be eliminated by introducing carbon dioxide into the diet of animals, and by injecting calcium gluconate.

The biological role of magnesium is multifaceted, as it is an essential element of many biochemical processes. Magnesium plays an important role as an enzyme activator, and usually has no direct effect on the reproductive status of animals (Linlin et al., 2013). However, its deficiency is associated with some gynecological pathologies and often leads to serious complications of pregnancy (Gromova et al., 2008). Sufficient provision of the mother's body with this important element creates the basis for full fetal development and the birth of healthy offspring. The need of a pregnant females' organism for magnesium often exceeds its supply, and this fact allows researchers to consider the pregnancy as a physiological model of hypomagnesemia. Therefore, magnesium deficiency during pregnancy can cause adverse effects on both mother and fetus, impaired embryo implantation, placental pathology, threatened abortion, premature birth, and weakness of labor were taken into consideration (Dadak, 2013; Rosner et al., 2016).

Jeong et al. (2018) found a positive relationship among serum magnesium concentration, peri and postpartum disorders, and reproductive performance in dairy cows. There are increasingly recent data on the regulatory role of magnesium on hormonal, namely on the reproductive function of the body (Strizhakov et al., 2009). Thus, Chandra et al. (2013) described the apparent beneficial effects of magnesium on the male gonadal system, including testicular histology, steroidogenesis, and spermatogenesis. Maggio et al. (2011) found a significant direct relationship between magnesium levels and serum testosterone levels. However, information about the mechanism of this dependence in the scientific literature is not enough. In the body, magnesium remains antagonistic to calcium, and any disturbances in the homeostasis of calcium-phosphorus-magnesium may have some effect on the reproduction (Yasothai, 2014).

Potassium plays an important role in the excitation of nerve and muscle tissue and is involved in carbohydrate metabolism. It maintains normal osmotic pressure and is of great importance in the processes of water metabolism. In addition, potassium specifically affects the activity of many enzymes (Koshovyj, 2004). Potassium iodide has a positive effect on the functional activity of the reproductive system. Potassium iodide preparations have a protective effect for the prevention of pathologies of pregnancy and the treatment of breast diseases (Pan'kiv, 2016).

Pavlova et al. (2014) established the undoubted positive effect of potassium humate on the reproductive system and determined that even exposure to it generally leads to positive biological consequences. This was manifested in males in an increase in the mass ratio of testes; reduction of pathological forms of sperm, and in females - in the reduction of atretic ovarian bodies, and an increase in the number of mature follicles. Karow et al. (1992) noted the positive effect of adding $\mathrm{K}^{+}$to media for sperm survival. Brainard et al. (2007) indicated the role of potassium ion channels in the regulation of myometrial tone during pregnancy. In particular, during gestation, potassium channels support the uterus at rest, promoting membrane resting potential and counteracting contractile stimuli.

Concerning the effect of potassium on reproductive function, Vizner (1976) reported that during heat or after estrogen administration to spayed animals, the potassium content in the endometrium increases, and the sodium concentration decreases. The introduction of progesterone causes the opposite effect meaning that a decrease in potassium levels and an increase in sodium content were noted. Although no direct effect has been identified, it should be assumed that these sex-related changes affect animal reproduction.

Sodium is needed to build new body tissues and plays an important role in water metabolism. An important function of sodium in the body is to maintain normal osmotic pressure in body fluids. This element is the main cation that determines the amount of reserve alkalinity of blood plasma and acid-base state of the body (Koshovyj, 2004).

Sodium deficiency can cause placental retention in cows and sexual rhythm disorders (Vizner, 1976). Beljaev et al. (2007) showed that the use of sodium selenite helps to improve the reproductive functions of sows. The results of the research by Posohova (2004) indicated a beneficial effect of sodium humate on the condition of animals, particularly in pregnant individuals, which is manifested in the improvement of their reproductive function, the development of more complete offspring.

The sodium humate has a positive effect on the reproductive function of cows in the postpartum period, in particular, its use can reduce the level of prenatal and postpartum complications, facilitate the course of labor, and increase the safety of offspring (Ushkalov, 2001; Bezuglova and Zinchenko, 2016). An important role in metabolism belongs to micronutrients, the deficiency of which differently affects the function of individual organs, including the genital organs (Smith and Akinbamijo, 2000; Ballantine et al., 2002; Ojha, et al., 2018). In biogeochemical provinces where soil, water, and feed are poor in iodine, manganese, copper, zinc, cobalt, and selenium, animal infertility is often observed (Corah and Ives, 1991; Ermakov et al., 2012).

Iodine is actively involved in the functions of all female genitals. The process of reproduction is significant metabolic stress in the genital organs, which can lead to acute iodine deficiency (Abdul-Fadle and Ayoub, 1970; Koshovyj, 2004). Iodine affects the synthesis of thyroid hormones, the activity of which during estrus is higher than in other phenomena of the sexual cycle (Yasothai, 2014). Therefore, signs of iodine deficiency are delayed puberty, 
suppressed or irregular estrus (Puls, 1994). Iodine is also important for fetal development (Yasothai, 2014). Infertility, abortion, placental delay, stillbirth, or low viability have been reported in animals with iodine deficiency (Keen and Hurley, 1989). However, by adding iodine to the diet, these pathological processes can be eliminated relatively quickly (Vizner, 1976; Koshovyj, 2004).

Cobalt is a trace element that the body needs in such small quantities, but its functional impact is significant. The physiological role of cobalt is diverse, and infertility due to hypocobaltosis is likely to occur as a secondary consequence of impaired overall metabolism (Yasothai, 2014). Hypocobaltosis disrupts the synthesis of nucleic acids, muscle proteins, the activity of hydrolytic enzymes which causes delayed puberty, reduced fertility, abortion, hypofunction and subinvolution of the uterus, retention of placenta, and the birth of animals with reduced vital activity (Puls, 1988; Hurley and Doane, 1989).

Copper is also considered an important mineral for reproduction (Yasothai, 2014). It is involved in several enzyme structures, and is an integral component of redox processes and carbohydrate metabolism, the level of which affects the reproductive function and activity of sex hormones (Hurley and Doane, 1989). The activity of some endocrine glands is associated with the presence of copper, in particular, the formation of hormones in the pituitary gland that stimulate the function of the gonads (Koshovyj, 2004). Copper deficiency is manifested mainly in reproductive disorders of females, particularly in the embryonic and neonatal periods of development. Reviewing the works of numerous authors has indicated that copper deficiency in cows has a negative effect on reproductive function, such as defective sexual cycles, arrhythmia, reduced fertility, embryo resorption, delayed placenta, the birth of calves with low vital activity (Vizner, 1976; O’Dell, 1990). Furthermore, the addition of copper improves sperm quality (Puls, 1988; Yasothai, 2014).

Manganese is a part of many enzymes promoting the action of various vitamins. Manganese is necessary for the development and functioning of the reproductive system of animals since it accumulates in large quantities in the adrenal glands, ovaries, and uterus, especially during pregnancy (Vizner, 1976). Manganese deficiency inhibits the puberty of animals, the growth, development, and maturation of follicles in females, as well as irregular sexual cycles or prolonged periods of anestrus and abortion (Brown and Casillas, 1986; Corah, 1996; Yasothai, 2014).

Manganese deficiency was observed mainly in ruminants, birds, and less often in pigs. In ruminants, they are characterized by low fertility, abortion, and other disorders of reproductive function. With manganese deficiency in the body, there is a slowdown in sexual development in females, and the birth of calves with various abnormalities (Koshovyj, 2004). Manganese is important in the synthesis of cholesterol (Keen and Zidenberg-Cheer, 1990), which in turn is required for the synthesis of steroids such as progesterone, estrogen, and testosterone. Decreased concentrations of these steroids in the circulation due to manganese deficiency can lead to related reproductive pathology (Yasothai, 2014). Summarizing the above, it can be maintained that manganese plays a significant role in the body and that the deficiency of this element in the diet leads to significant violations of all parameters of reproduction (Plumlee et al., 1956; Hurley and Doane, 1989). Molybdenum belongs only to the micronutrients that are conditionally necessary for animals (Wirth and Mijal, 2010). Zhai et al. (2013) found a positive effect of molybdenum on human sperm quality, Zhang et al. (2013) reported the good quality of oocytes, and Bi et al. (2013) revealed findings about the impact of molybdenum on the development of preimplantation embryos. Reproductive disorders due to molybdenum deficiency are described, in males as decreased libido, impaired spermatogenesis, and sterility, and there were reports of delayed puberty, reduced fertility, and anestrus in females (Yasothai, 2014). However, molybdenum deficiency is a rare phenomenon, and its excess with toxic effects is more often registered (Corah and Ives, 1991).

Selenium is involved in aerobic oxidation by regulating the rate of redox reactions and is considered an essential biologically active microelement. It is effective in treating many diseases and infertility in animals (Mehdi and Dufrasne, 2016). In addition, it regulates the absorption and consumption of Vitamins A, C, K, and, especially Vitamin E, in the body, enhancing their effect. In terms of its effect on the body, this microelement is similar in its effect on Vitamin E. It is believed that the mechanism of action of Vitamin $\mathrm{E}$ and selenium on the fertility and reproductive health of animals is based on the detection of antioxidant properties of these compounds. By protecting cells from reactive oxygen species, Vitamin E and selenium prevent damage to sperm, ovicells, and embryos, and are involved in supporting the immune function of animals (Hurley and Doane, 1989; Gabryszuk and Klewiec, 2002; Albanes et al., 2014).

The safety margin (difference between a normal requirement and toxic dose) for selenium is so narrow that its deficiency in farm animals is quite rare than its toxicity, but causes weak, latent, or irregular estrus, early embryonic mortality, birth of weak offspring, and abortions in females, inhibition of spermatogenesis and deterioration of sperm quality in males (Hurley and Doane, 1989; Yasothai, 2014; Ojha et al., 2018). Selenium deficiency in diets leads to resorption of embryos, delayed placenta, infertility, and mastitis. There is evidence indicating that selenium deficiency increases the frequency of abortions (Hedstrom et al., 1986). The use of selenium drugs reliably prevents these pathological processes (Giadinis et al., 2016; Khalili et al., 2020).

Among the essential microelements, a special place is occupied by zinc, which is present in all cells of the body, and participates in various metabolic processes in the active centers of more than 200 enzymes (Prasad, 2003; Beleckaja and Onul, 2014). Zinc is necessary for the body for the respiratory process, activating the function of many enzymes, 
affecting the metabolism and activity of sex and gonadotropic hormones of the pituitary gland, and playing an important role in optimizing fertilization and reproduction of animals (Koshovyj, 2004). Zinc is known to be important in puberty (development of secondary sexual characteristics), reproductive capacity in males (gonadal cell development and sperm quality), and all reproductive events (heat, pregnancy, and lactation) in females (Maas, 1987). In addition, zinc plays a crucial role in the restoration and maintenance of the uterine mucosa after childbirth and the early period of return to normal reproductive function and estrus (Greene et al., 1998; Yasothai, 2014). A large number of studies have described the effect of zinc deficiency in males, in particular, its importance for normal spermatogenesis and steroidogenesis (Keen and Hurley, 1989). Zinc is also involved in the gestational health of the newborn and mother, and its deficiency is a factor in the increased risk of placental abruption, premature rupture of membranes, premature birth, and weakness of labor (Jameson, 1993; Scholl et al., 1993; Christian, 2003). In addition, its insufficiency leads to suppression of gonadal function and estrogenic activity. This condition in animals causes a decrease in reproductive activity although it has been reported infrequently (Jameson, 1976; Keen and Hurley, 1989).

The value of cadmium for reproduction should be sought primarily in its antagonistic action on zinc. An even stronger antagonism is attributed to cadmium relative to copper, a deficiency of which is noted for cadmium overdose (Vishnjakov and Lebedev, 2011; Zhegalova et al., 2018). However, as theory and practice show, cadmium toxicosis of alimentary origin in animals is unlikely (Vizner, 1976). In addition, there is a piece of evidence to negate the negative effects of cadmium on reproductive function (Lafuente et al., 2002). Moreover, the results of research by Thomas (1993) suggested that cadmium can have a direct effect on the level of the pituitary gland by altering gonadotropins. The data of Lafuente et al. (2003) declared that cadmium differently affects the secretory mechanisms of the studied pituitary hormones depending on the dose. Keck et al. (1995) found no significant correlation between sperm cadmium concentration and normal sperm parameters or between cadmium concentration and fertility status.

Iron deficiency anemia is a well-known risk factor for pregnancy complications, such as intrauterine growth retardation and fetal development, preterm birth, low birth weight, postpartum hemorrhage, maternal and infant mortality (Baker, 2000; Georgieff, 2020). In the first months of life, the main source of iron for a neonatal animal is the iron transferred via the utero of the mother to the fetus, so a pregnant female must receive a sufficient amount of this microelement (Cetin et al., 2010; Berger et al., 2011; Caserta et al., 2013). Data from Murray-Kolb and Beard (2009) suggested that iron deficiency in the mother adversely affects the mother-child interaction, and iron supplementation protects them against these adverse effects.

Saliy et al. (2013) noted the importance of iron deficiency in the formation of reproductive disorders in hypothalamic dysfunction of puberty, the extreme expression of which is the hypothalamic syndrome of puberty, leading to infertility and miscarriage in the reproductive age. Saliy et al. (2013) noted that this nature of the changes may have clinical and diagnostic value in assessing the severity of the reproductive dysfunction in this pathology. Siemons and Mahler (1987) reported the role of iron deficiency in the development of hypogonadotropic hypogonadism, manifested by a lack of libido and aspermia. The use of iron supplements helped to restore reproductive function.

Chromium is one of the "young" microelements, as its functions in the animal body are still not fully disclosed, but the undeniable importance of this element for health has been proved (Kisljakova and Lomaeva, 2017). Chromium is a vital microelement that is a constant component of cells of all organs and tissues, one of the functions of which is to participate in the regulation of fat synthesis and carbohydrate metabolism. Increased costs are observed during pregnancy, and one of the main manifestations of its deficit is a violation of the reproductive function in males (Reutina, 2009). In particular, Anderson and Polansky (1981) reported that male chromium-deficient rats had reduced sperm and sperm cell counts and reduced fertility.

Chromium has a significant effect on follicle maturation and the release of luteinizing hormone (Sheela and Ajay, 2004). In addition, chromium enhances the effects of insulin by increasing the absorption of glucose and amino acids through the body's cells, and thereby, improving energy balance, which leads to improved reproductive function (Stoecker, 1990). It is confirmed that the addition of chromium propionate to the basic diet of cows can improve the reproductive functions of animals, in particular, to reduce the percentage of abnormal births, cases of the delayed placenta, and the duration of the service period (Kisljakova and Lomaeva, 2017).

The data obtained by Serjakov and Judina (2014) indicated that the introduction of sows into the diet could increase fertility, litter weight at birth, average live weight of piglets at birth, milk yield, weight of piglets, and litter during weaning and storage of piglets during suckling.

\section{CONCLUSION}

Thus, vitamins, micro-, and macroelements are alimentary-deficient factors of disturbance of reproductive function of animals, the influence of which is observed in all reproduction processes, from fertilization to the postpartum period and the preservation of young animals. The pathogenesis of their insufficiency is associated with a violation of steroidogenesis, gametogenesis, and embryogenesis and the emergence of ante, intra, neo, and postnatal pathologies. 
Therefore, treatment and prevention measures should be aimed at providing animals with biologically complete balanced feeding and replenishment of the body with vitamins and minerals. However, all these issues remained incompletely studied and further research of their impact on the manifestation of animal reproductive functions are needed.

\section{DECLARATIONS}

\section{Authors' contributions}

P. Skliarov designed the main idea and wrote the review. S. Fedorenko, S. Naumenko, O. Onyshchenko, A. Pasternak, L. Roman, M. Lieshchova, D. Bilyi, and O. Bobrytska equally involved in the searching of literature review, writing up the paper, and critically analyzing the core idea of the paper, and reviewing the manuscript. All authors approved the final submitted version and the data analysis.

\section{Consent to publish}

The authors approved and agreed to publish the manuscript.

\section{Competing interests}

The authors have declared no conflict of interest. Ethical issues (including plagiarism, double publication and/or submission, and redundancy) have been checked by the authors.

\section{REFERENCES}

Abdul-Fadle W, and Ayoub LA (1970). Iodine metabolism in relation to reproductive status in cows. Zentralblatt fur Veterinarmedizin, 17(1): 62-67. DOI: https://www.doi.org/10.1111/j.1439-0442.1970.tb00775.x

Albanes D, Till C, Klein EA, Goodman PJ, Mondul AM, Weinstein S, Taylor PR, Parnes HL, Gaziano JM, Song X et al. (2014). Plasma tocopherols and risk of prostate cancer in the selenium and Vitamin E cancer prevention trial (SELECT). Cancer Prevention Research, 7(9): 886-895. DOI: https://www.doi.org/10.1158/19406207.CAPR-14-0058

Amin Rooh Ul (2014). Nutrition: Its role in reproductive functioning of cattle - a review. Veterinary Clinical Science, 2(1): 1-9. Available at: http://jakraya.com/journal/pdf/2-vcsArticle_1.pdf

Anderson RA, and Polansky MM (1981). Dietary chromium deficiency effect on sperm count and fertility in rats. Biological Trace Element Research, 3(1): 1-5. DOI: https://www.doi.org/10.1007/bf02789119

Baczyk D, Kingdom JC, and Uhlén P (2011). Calcium signaling in placenta. Cell Calcium, 49: 350-356. DOI: https://www.doi.org/10.1016/j.ceca.2010.12.003

Baker WF Jr (2000). Iron deficiency in pregnancy, obstetrics, and gynecology. Hematology/Oncology Clinics of North America, 14(5): 1061-1077. DOI: https://www.doi.org/10.1016/s0889-8588(05)70171-4

Baldoceda-Baldeon LM, Gagné D, Vigneault C, Blondin P, and Robert C (2014). Improvement of bovine in vitro embryo production by Vitamin K (2) supplementation. Reproduction, 148(5): 489-497. DOI: https://www.doi.org/10.1530/rep-14-0324

Ballantine HT, Socha MT, Tomlinson DAD, Johnson AB, Fielding AS, Shearer JK, and Van Amstel SR (2002). Effects of feeding complexed zinc, manganese, copper, and cobalt to late gestation and lactating dairy cows on claw integrity, reproduction, and lactation performance. The Professional Animal Scientist, 18(3): 211-218. DOI: https://www.doi.org/10.15232/S1080-7446(15)31524-2

Beleckaja JN, and Onul NM (2014). The effect of zinc on the reproductive function of experimental animals. Mikrojelementy v Medicine, 15(2): 2228. Available at: https://elibrary.ru/item.asp?id=21692639

Beljaev VI, Shabunin SV, and Balym JP (2007). The influence of selenium preparations on the productivity and reproductive functions of sows. Veterinarnyj Vrach, 2: 38-40. Available at: https://elibrary.ru/item.asp?id=11732988

Berger J, Wieringa FT, Lacroux A, and Dijkhuizen MA (2011). Strategies to prevent iron deficiency and improve reproductive health. Nutrition Reviews, 69(1): 78-86. DOI: https://www.doi.org/10.1111/j.1753-4887.2011.00436.x

Bezuglova OS, and Zinchenko VE (2016). The use of humic preparations in animal husbandry (review). Dostizhenija Nauki i Tehniki APK, 30(2): 8993. Available at: https://cyberleninka.ru/article/n/primenenie-guminovyh-preparatov-v-zhivotnovodstve-obzor/viewer

Bindari YR, Shrestha S, Shrestha N, and Gaire TN (2013). Effects of nutrition on reproduction - A review. Advances in Applied Science Research, 4(1): 421-429. Available at: https://www.imedpub.com/articles/effects-of-nutrition-on-reproduction-a-review.pdf

Blaner WS, Li Y, Brun PJ, Yuen JJ, Lee SA, and Clugston RD (2016). Vitamin A absorption, storage and mobilization. The Biochemistry of Retinoid Signaling. Springer, Dordrecht, pp. 95-125. DOI: https://www.doi.org/10.1007/978-94-024-0945-1_4

Bohstedt G (1942). Minerals in dairy cattle nutrition: A review. Journal of Dairy Science, 25(5): 441-458. DOI: https://www.doi.org/10.3168/jds.s0022-0302(42)95312-8

Bourdeau JE, Schwer-Dymerski DA, Stern PH, and Langman CB (1986). Calcium and phosphorus metabolism in chronically vitamin D-deficient laboratory rabbits. Mineral and Electrolyte Metabolism, 12(3): 176-185. Available at: https://pubmed.ncbi.nlm.nih.gov/3755216/

Brainard AM, Korovkina VP, and England SK (2007). Potassium channels and uterine function. Seminars in Cell and Developmental Biology, pp. 332-339. DOI: https://www.doi.org/10.1016/j.semcdb.2007.05.008.

Briggs MH (1973). Vitamin C and infertility. Lancet, 2: 677-678. DOI: https://www.doi.org/10.1016/s0140-6736(73)92513-0

Brommage R, Baxter DC, and Gierke LW (1990). Vitamin D-independent intestinal calcium and phosphorus absorption during reproduction.American Journal of Physiology-Gastrointestinal and Liver Physiology, 259(4): 631-638. DOI: https://www.doi.org/10.1152/ajpgi.1990.259.4.g631

Brown MA, and Casillas ER (1986). Manganese and manganese-ATP interactions with bovine sperm adenylate cyclase. Archives of Biochemistry and Biophysics, 244(2): 719-726. DOI: https://www.doi.org/10.1016/0003-9861(86)90641-7

Caserta D, Graziano A, Monte GL, Bordi G, and Moscarini M (2013). Heavy metals and placental fetal-maternal barrier: a mini-review on the major concerns. European Review for Medical and Pharmacological Sciences, 17(16): 2198-2206. Available at: https://pubmed.ncbi.nlm.nih.gov/23893187/

Catt KJ, Loumaye E, Wynn PC, Iwashita M, Hirota K, Morgan RO, and Chang JP (1985). GnRH receptors and actions in the control of reproductive function. Journal of Steroid Biochemistry, 23(5): 677-689. DOI: https://www.doi.org/10.1016/s0022-4731(85)80003-0 
Cetin I, Berti C, and Calabrese S (2010). Role of micronutrients in the periconceptional period. Human Reproduction Update, 16(1): 80-95. DOI: https://www.doi.org/10.1093/humupd/dmp025

Chandra AK, Sengupta P, Goswami H, and Sarkar M (2013). Effects of dietary magnesium on testicular histology, steroidogenesis, spermatogenesis and oxidative stress markers in adult rats. Indian Journal of Experimental Biology, 51: 37-47. Available at: https://pubmed.ncbi.nlm.nih.gov/23441478/

Christian P (2003). Micronutrients and reproductive health issues: An international perspective. The Journal of Nutrition, 133(6): 1969-1973. DOI: https://www.doi.org/10.1093/jn/133.6.1969s

Corah L (1996). Trace mineral requirements of grazing cattle. Animal Feed Science and Technology, 59: 61-70. DOI: https://www.doi.org/10.1016/0377-8401(95)00887-x

Corah LR, and Ives S (1991). The effects of essential trace minerals on reproduction in beef cattle. Veterinary Clinics of North America: Food Animal Practice, 7(1): 41-57. DOI: https://www.doi.org/10.1016/S0749-0720(15)30809-4

Correia J, Michelangeli F, and Publicover S (2015). Regulation and roles of $\mathrm{Ca}^{2+}$ stores in human sperm. Reproduction, 150: 65-76. DOI: https://www.doi.org/10.1530/REP-15-0102

Dadak K (2013). Magnesium deficiency in obstetrics and gynecology. Akusherstvo, ginekologija i reprodukcija, 7(2): 6-14. Available at: https://www.gynecology.su/jour/article/view/13?locale=en_US

Dawson EB, Harris WA, and Powell LC (1990). Relationship between ascorbic acid and male fertility. World Review of Nutrition and Dietetics, 62: 126. DOI: https://www.doi.org/10.1159/000417532

Di Cio AV, and Schteingart M (1942). The influence of ascorbic acid on the activity of gonadotrophic hormones. Endocrinology, 30: 263-264. DOI: https://www.doi.org/10.1210/endo-30-2-263

Ermakov VV, Karpova EA, Korzh VD, and Ostroumov SA (2012). Innovative aspects of biogeochemistry. Moskva, p. 340 . Available at: https://5bio5.blogspot.com/2019/08/23-1.html

Evans HM, and Bishop KS (1922). On the existence of a hitherto unrecognized dietary factor essential for reproduction. Science, 56: 650-651. DOI: https://www.doi.org/10.1126/science.56.1458.650

Finkelstein JL, Layden AJ, and Stover PJ (2015). Vitamin B-12 and perinatal health. Advances in Nutrition, 6(5): 552-563. DOI: https://www.doi.org/10.3945/an.115.008201

Gabryszuk M, and Klewiec J (2002). Effect of injecting 2- and 3-year-old ewes with selenium and selenium-vitamin E on reproduction and rearing of lambs. Small Ruminant Research, 43(2): 127-132. DOI: https://www.doi.org/10.1016/S0921-4488(02)00005-6

Georgieff MK (2020). Iron deficiency in pregnancy. American Journal of Obstetrics and Gynecology, 223(4): 516-523. DOI: https://www.doi.org/10.1016/j.ajog.2020.03.006

Giadinis ND, Loukopoulos P, Petridou EJ, Panousis N, Konstantoudaki K, Filioussis G, Tsousis G, Brozos C, Koutsoumpas AT, Chaintoutis SC et al. (2016). Abortions in three beef cattle herds attributed to selenium deficiency. Pakistan Veterinary Journal, 36: 145-148. Available at: https://researchoutput.csu.edu.au/en/publications/abortions-in-three-beef-cattle-herds-attributed-to-selenium-defic

Golovanova VA, and Strokova OA (2011). The functional state of the reproductive system of young women in conditions of a deficiency of antioxidant complex vitamins. Vestnik Orenburgskogo gosudarstvennogo universiteta, 16(135): 261-263. Available at: https://cyberleninka.ru/article/n/funktsionalnoe-sostoyanie-reproduktivnoy-sistemy-molodyh-zhenschin-v-usloviyah-defitsita-vitaminovantioksidantnogo-kompleksa

Greene LW, Johnson AB, Paterson J, and Ansotegui R (1998). Role of trace minerals in cow-calf cycle examined. Feedstuffs, 70(27): 12-17. Available at: https://agris.fao.org/agris-search/search.do?recordID=US1997078392

Gromova OA, Serov VN, and Torshin IJ (2008). Magnesium in obstetrics and gynecology: A history of application and modern views. Trudnyj Pacient, 6(8): 10-15. Available at: https://cyberleninka.ru/article/n/magniy-v-akusherstve-i-ginekologii-istoriya-primeneniya-i-sovremennyevzglyady/viewer

Gromova OA, Torshin IJ, Tetruashvili NK, Kodencova VM, and Rudakov KV (2019). Vitamin A in obstetrics: basic and clinical research. Medicinskij Alfavit, 1(1): 59-69. DOI: https://www.doi.org/10.33667/2078-5631-2019-1-1(376)-59-69

Gromova OA, Torshin IY, Grishina TR, and Malyavskaya SI (2017). On the role of vitamin D in the prevention and treatment of male infertility. Kachestvennaya Klinicheskaya Praktika, 3: 61-71. https://cyberleninka.ru/article/n/o-rolyah-vitamina-d-v-profilaktike-i-terapii-muzhskogobesplodiya

Gullickson TW, Palmer LS, Boyd WL, Nelson JW, Olson P, Calverley CE, and Boyer PD (1949). Vitamin E in the nutrition of cattle. 1. Effect of feeding Vitamin E poor rations on reproduction, health, milk production, and growth. Journal of Dairy Science, 32: 495-508. DOI: https://www.doi.org/10.3168/jds.S0022-0302(49)92071-8

Hedstrom OR, Maas JP, Hultgren BD, Lassen ED, Wallner-Pendleton EA, and Snyder SP (1986). Selenium deficiency in bovine, equine, and ovine with emphasis on its association with chronic diseases. In: 29 Annual Proceedings American Association of Veterinary Laboratory Diagnosticians (USA), pp. 101-121. Available at: https://agris.fao.org/agris-search/search.do?recordID=US8735979

Hertz R (1946). Effect of B vitamins on the endocrinological aspects of reproduction. In: Vitamins and Hormones. Academic Press, pp. 135-146. DOI: https://www.doi.org/10.1016/S0083-6729(08)61081-X

Hogarth CA, and Griswold MD (2010). The key role of vitamin A in spermatogenesis. The Journal of Clinical Investigation, 120(4): 956-962. DOI: https://www.doi.org/10.1172/jci41303

Hovdenak N, and Haram K (2012). Influence of mineral and vitamin supplements on pregnancy outcome. European Journal of Obstetrics and Gynecology and Reproductive Biology, 164(2): 127-132. DOI: https://www.doi.org/10.1016/j.ejogrb.2012.06.020

Huber AM, Davidson KW, O'Brien-Morse ME, and Sadowski JA (1999). Tissue phylloquinone and menaquinones in rats are affected by age and gender. The Journal of Nutrition, 129(5): 1039-1044. DOI: https://www.doi.org/10.1093/jn/129.5.1039

Hurley WL, and Doane RM (1989). Recent developments in the roles of Vitamins and minerals in reproduction. Journal of Dairy Science, 72(3): $784-$ 804. DOI: https://www.doi.org/10.3168/jds.s0022-0302(89)79170-0

Hurley WL, Edgerton LA, Olds D, and Hemken RW (1982). Estrous behavior and endocrine status of dairy heifers with varied intakes of phosphorus. Journal of Dairy Science, 65(10): 1979-1986. DOI: https://www.doi.org/10.3168/jds.s0022-0302(82)82447-8

Ibtisham F, Nawab AAMIR, Li G, Xiao M, An L, and Nasee G (2018). Effect of nutrition on reproductive efficiency of dairy animals. Medycyna Weterynaryjna, 74(6): 356-361. DOI: https://www.doi.org/10.21521/mw.6025

Iolchiev BS, Kononov VP, Tadzhieva AV, Bagirov VA, D'jakevich ON, and Mambetaliev MA (2014). Factors affecting the level of reproduction of cows in modern dairy cattle breeding. Agrarnaja Rossija, (12): 18-21. DOI: https://www.doi.org/10.30906/1999-5636-2014-12-18-21

Irani M, and Merhi Z (2014). Role of Vitamin D in ovarian physiology and its implication in reproduction: a systematic review. Fertility and Sterility, 102(2): 460-468. DOI: https://www.doi.org/10.1016/j.fertnstert.2014.04.046

Jacob J, Endepols S, Pelz HJ, Kampling E, Cooper TG, Yeung CH, Redmann K, and Schlatt S (2012). Vitamin K requirement and reproduction in bromadiolone-resistant Norway rats. Pest Management Science, 68(3): 378-385. DOI: https://www.doi.org/10.1002/ps.2273 
Jameson S (1976). Effects of zinc deficiency in human reproduction. Acta Medica Scandinavica, 593: 1-89. Available at: https://pubmed.ncbi.nlm.nih.gov/1067745/

Jameson S (1993). Zinc status in pregnancy: the effect of zinc therapy on perinatal mortality, prematurity, and placental ablation. Annals of the New York Academy of Sciences, 678(1): 178-192. DOI: https://www.doi.org/10.1111/j.1749-6632.1993.tb26121.x

Jeong JK, Choi IS, Moon SH, Kang HG, and Kim IH (2018). Relationship between serum magnesium concentration during the transition period, periand postpartum disorders, and reproductive performance in dairy cows. Livestock Science, 213: 1-6. DOI: https://www.doi.org/10.1016/j.livsci.2018.04.013

Kagermazov CB, and Taov IH (2018). The influence of external environmental conditions on the reproductive function of cows in the conditions of the Kabardino-Balkarian Republic. Agrarnaja Rossija, 10: 37-40. DOI: https://www.doi.org/10.30906/1999-5636-2018-10-37-40

Kalinchenko SJ, Zhilenko MI, Gusakova DA, Tjuzikov R, Mshalaja GZ, Sablin KS, and Dymova AV (2016). Vitamin D and Women's Reproductive Health. Problemy Reprodukcii, 22(4): 28-36. DOI: https://www.doi.org/10.17116/repro201622428-36

Karow AM, Gilbert WB, and Black JB (1992). Effects of temperature, potassium concentration, and sugar on human spermatozoa motility: A cell preservation model from reproductive medicine. Cryobiology, 29(2): 250-254. DOI: https://www.doi.org/10.1016/0011-2240(92)90023-U

Keck C, Bramkamp G, Behre HM, Müller C, Jockenhövel F, and Nieschlag E (1995). Lack of correlation between cadmium in seminal plasma and fertility status of nonexposed individuals and two cadmium-exposed patients. Reproductive Toxicology, 9(1): 35-40. DOI https://www.doi.org/10.1016/0890-6238(94)00053-Y

Keen CL and Hurley LS (1989). Zinc and reproduction: effects of deficiency on foetal and postnatal development. In: Zinc in human biology. Springer, London, pp. 183-220. DOI: https://www.doi.org/10.1007/978-1-4471-3879-2_12

Keen CL, and Zidenberg-Cheer S (1990). Manganese. In: Present knowledge in nutrition. ML Brown (Ed). International life Science Institute. Washington DC, Nutrition Foundation, pp. 279-288. Available at: https://ci.nii.ac.jp/naid/10011118264/

Khalili M, Chamani M, Amanlou H, Nikkhah A, Sadeghi AA, Dehkordi FK, Rafiei M, and Shirani V (2020). The effect of feeding inorganic and organic selenium sources on the hematological blood parameters, reproduction and health of dairy cows in the transition period. Acta Scientiarum. Animal Sciences, 42: e45371. DOI: https://www.doi.org/10.4025/actascianimsci.v42i1.45371

Kisljakova EM, and Lomaeva AA (2017). The effect of organic chromium additives on the productive and reproductive performance of black and white cows. Uchenye zapiski Kazanskoj gosudarstvennoj akademii veterinarnoj mediciny im. Baumana, 232(4): 76-80. Available at: https://cyberleninka.ru/article/n/vliyanie-dobavok-organicheskogo-hroma-na-produktivnye-i-reproduktivnye-pokazateli-korov-cherno-pestroyporody/viewer

Kornbluth S, and Fissore R (2015). Vertebrate reproduction. Cold Spring Harbor Perspectives in Biology, 7: a006064. DOI: https://www.doi.org/10.1101/cshperspect.a006064

Koshovyj VP (2004). Obstetric-gynecologic pathology in cows. Harkiv, pp. 5-70. Available at: http://www.irbis-nbuv.gov.ua/cgibin/irbis nbuv/cgiirbis 64.exe

Koshovyj VP (2008). Veterinary perinatology. Harkiv, pp. 9-459. Available at: https://dspace.dsau.dp.ua/jspui/handle/123456789/749

Kovacs CS (2015). Calcium, phosphorus, and bone metabolism in the fetus and newborn. Early Human Development, 91: 623-628. DOI: https://www.doi.org/10.1016/j.earlhumdev.2015.08.007

Kuz'minova EV, Semenenko MP, Koshhaev AG, and Troshin AN (2017). Biological functions of carotenoids in cattle reproduction. Politematicheskij Setevoj Jelektronnyj Nauchnyj Zhurnal Kubanskogo Gosudarstvennogo Agrarnogo Universiteta, 129: 1124-1136. DOI: https://www.doi.org/10.21515/1990-4665-129-080

Lafuente A, Cano P, and Esquifino AI (2003). Are cadmium effects on plasma gonadotropins, prolactin, ACTH, GH and TSH levels, dose-dependent? Biometals, 16(2): 243-250. DOI: https://www.doi.org/10.1023/a:1020658128413

Lafuente A, González-Carracedo A, Márquez N, Pazo D, and Esquifino AI (2002). Oral cadmium exposure throughout puberty does not inhibit secretion of prolactin, GH and ACTH through dopamine metabolism changes in male rat. Journal of Trace Elements in Medicine and Biology, 16(4): 249-254. DOI: https://www.doi.org/10.1016/S0946-672X(02)80053-0

Leclerc C, Néant I, and Moreau M (2011). Early neural development in vertebrates is also a matter of calcium. Biochimie, 93: 2102-2111. DOI: https://www.doi.org/10.1016/j.biochi.2011.06.032

Lewis H, and Everson G (1952). Deposition of B vitamins in normally developing fetuses as evidence for increased vitamin needs of the rat for reproduction: II. pantothenic acid and biotin, two figures. The Journal of Nutrition, 46(1): 27-35. DOI: https://www.doi.org/10.1093/jn/46.1.27

Linlin G, Hailong J, and Guixin Q (2013). Effect and possible mechanism of magnesium on reproductive performance of sows. Feed Industry, p. 5. Available at: https://en.cnki.com.cn/Article_en/CJFDTotal-FEED201305006.htm

Luck MR, and Scanes CG (1979). The relationship between reproductive activity and blood calcium in the calcium-deficient hen. British Poultry science, 20(6): 559-564. DOI: https://www.doi.org/10.1080/00071667908416621

Luck MR, Jeyaseelan I, and Scholes RA (1995). Ascorbic acid and fertility. Biology of Reproduction, 52(2): 262-266. DOI https://www.doi.org/10.1095/biolreprod52.2.262

Luk J, Torrealday S, Neal Perry G, and Pal L (2012). Relevance of Vitamin D in reproduction. Human Reproduction, 27(10): 3015-3027. DOI: https://www.doi.org/10.1093/humrep/des248

Maas J (1987). Relationship between nutrition and reproduction in beef cattle. The Veterinary Clinics of North America. Food Animal Practice, 3(3): 633-646. DOI: https://www.doi.org/10.1016/s0749-0720(15)31135-x

Maggio M, Ceda GP, Lauretani F, Cattabiani C, Avantaggiato E, Morganti S, Ablondi F, Bandinelli S, Dominguez LJ, Barbagallo M et al. (2011). Magnesium and anabolic hormones in older men. International Journal of Andrology, 34: 594-600. DOI: https://www.doi.org/10.1111/j.13652605.2011.01193.x

Mahan DC, and Vallet JL (1997). Vitamin and mineral transfer during fetal development and the early postnatal period in pigs. Journal of Animal Science, 75(10): 2731-2738. Available at: https://www.doi.org/10.2527/1997.75102731x

Maia SB, Souza ASR, de Caminha MFC, da Silva SL, de Cruz R, Sá BLC, dos Santos CC, and Filho MB (2019). Vitamin A and Pregnancy. A Narrative Review. Nutrients, 11(3): Article number 681. DOI: https://www.doi.org/10.3390/nu11030681

Malysheva NV (2007). The influence of environmental and geochemical factors on the formation of reproductive function (PhD Thesis). GOU VPO «Orenburgskij gosudarstvennyj universitet», Moskva. Available at: https://www.dissercat.com/content/vliyanie-ekologo-geokhimicheskikhfaktorov-na-stanovlenie-reproduktivnoi-funktsii

Manalili SC, and Bernardo JC (1996). Reproductive performance of sows and breeding gilts induced with Apocrine S-oil with different levels of vitamin ADE supplementations. Araneta Research Journal, 34: 6-10. Available at: https://agris.fao.org/agrissearch/search.do?recordID=PH1998101052

Matte JJ, and Lauridsen C (2013). Vitamins and vitamin utilization in swine. In: Sustainable Swine Nutrition. Wiley-Blackwell, pp. 139-172. DOI: https://www.doi.org/10.1002/9781118491454.ch6 
Mehdi Y, and Dufrasne I (2016). Selenium in cattle: A review. Molecules, 21(4): 1-14. DOI: https://www.doi.org/10.1186/1751-0147-46$\underline{229.10 .3390 / \text { molecules } 21040545}$

Metta VC, and Johnson BC (1960). Effect of feeding vitamin K-deficient diets to female rats. The Journal of Nutrition, 72(4): 455-458. DOI: https://www.doi.org/10.1093/jn/72.4.455

Millar J (1992). Vitamin C - the primate fertility factor? Medical Hypotheses, 38: 292-295. DOI: https://www.doi.org/10.1016/0306-9877(92)90019-9

Moore RA, Bittenger I, Miller ML, and Hellman LM (1942). Abortion in rabbits fed a Vitamin K deficient diet. American Journal of Obstetrics and Gynecology, 43: 1007-1012. DOI: https://www.doi.org/10.1016/s0002-9378(42)91023-8

Murray-Kolb LE, and Beard JL (2009). Iron deficiency and child and maternal health. The American Journal of Clinical Nutrition, 89(3): 946-950. DOI: https://www.doi.org/10.3945/ajen.2008.26692D

O’Dell L (1990). In: Present knowledge in nutrition. ML Brown, Ed, International life Sciences Institute Foundation. Washington DC, pp. 261-267. Available at: https://ci.nii.ac.jp/naid/10011118264/

Ojha L, Grewal S, Singh AK, Pal RP, and Mir SH (2018). Trace minerals and its role on reproductive performance of farm animals. Journal of Entomology and Zoology Studies, 6(4): 1406-1409. Available at: https://www.entomoljournal.com/archives/2018/vol6issue4/PartX/6-3-330318.pdf

Omur A, Kirbas A, Aksu E, Kandemir F, Dorman E, Kaynar O, and Ucar O (2016). Effects of antioxidant vitamins (A, D, E) and trace elements (Cu, $\mathrm{Mn}, \mathrm{Se}, \mathrm{Zn}$ ) on some metabolic and reproductive profiles in dairy cows during transition period. Polish Journal of Veterinary Sciences, 19(4): 697-706. DOI: https://www.doi.org/10.1515/pjvs-2016-0088

Pan'kiv VI (2016). The influence of thyroid disorders upon the female reproductive function. modern possibilities of phytotherapy. Reproductive Endocrinology, (27): 52-57. DOI: https://www.doi.org/10.18370/2309-4117.2016.27.52-57

Pasynkova TS (2013). The effect of feeding on the reproductive function of cows. Vestnik Izhevskoj Gosudarstvennoj Sel'skohozjajstvennoj Akademii, 2: 17-18. Available at: https://elibrary.ru/item.asp?id=21018838

Pavlova ON, Pinaeva ON, Leonov VV, and Garipov TV (2014). The effect of potassium humate on the reproductive system of rats. Vestnik medicinskogo instituta «Reaviz»: Reabilitacija, Vrach i Zdorov'e, 3(15): 50-53. Available at: https://cyberleninka.ru/article/n/vliyanie-gumatakaliya-na-reproduktivnuyu-sistemu-krys/viewer

Perevozchikov AL, Batanov SD, Lopatina SA, and Mysik AT (2014). Intensification of the level of reproduction by rationed feeding of sows. $\begin{array}{llll}\text { Svynarstvo, } & \text { (65): } & \text { Available } & \text { at: }\end{array}$ bin/irbis nbuv/cgiirbis 64.exe?C21COM=2\&I21DBN=UJRN\&P21DBN=UJRN\&IMAGE FILE DOWNLOAD=1\&Image file name=PDF/sv un 2014_65 45.pdf

Pinelli-Saavedra A (2003). Vitamin E in immunity and reproductive performance in pigs. Reproduction Nutrition Development, 43(5): 397-408. DOI: https://www.doi.org/10.1051/rnd:2003034

Plemjashov KV (2010). The value of vitamins for animal reproduction. Sankt-Peterburg, p. 68. Available at: https://elibrary.ru/item.asp?id=45840392

Plumlee MP, Thrasher DM, Beeson WM, Andrews FN, and Parker HE (1956). The effects of a manganese deficiency upon the growth, development, and reproduction of swine. Journal of Animal Science, 15(2): 352-367. DOI: https://www.doi.org/10.2527/jas1956.152352x

Posohova AV (2004). Experimental biomedical study of the nutritional use of sodium humate (Abstract of doctoral dissertation). Vladivostok: Vladivostokskij Gosudarstvennyj Medicinskij Universitet, p. 25. Available at: http://medical-diss.com/medicina/eksperimentalnoe-medikobiologicheskoe-obosnovanie-pischevogo-ispolzovaniya-gumata-natriya

Potter EL (1945). The effect on infant mortality of Vitamin K administered during labor. American Journal of Obstetrics and Gynecology, 50: $235-247$. DOI: https://www.doi.org/10.1097/00006254-194602000-00008

Prasad AS (2003). Zinc deficiency: Has been known of for 40 years but ignored by global health organisations. British Medical Journal, 326(7386): 409-410. DOI: https://www.doi.org/10.1136/bmj.326.7386.409

Puls R (1988). Mineral levels in animal health. Diagnostic data. Sherpa international, Clearbrook. British Columbia, Canada, p. 240. Available at: https://www.cabdirect.org/cabdirect/abstract/19892283865

Ramakrishnan U, Manjrekar R, Rivera J, Gonzáles-Cossío T, and Martorell R (1999). Micronutrients and pregnancy outcome: A review of the literature. Nutrition Research, 19(1): 103-159. DOI: https://www.doi.org/10.1016/s0271-5317(98)00178-x

Reutina SV (2009). The role of chromium in the human body. Vestnik Rossijskogo universiteta druzhby narodov, 4: 50-55. Available at: https://cyberleninka.ru/article/n/rol-hroma-v-organizme-cheloveka/viewer

Reznikoff-Etiévant MF, Zittoun J, Vaylet C, Pernet P, and Milliez J (2002). Low vitamin B12 level as a risk factor for very early recurrent abortion. European Journal of Obstetrics and Gynecology and Reproductive Biology, 104(2): 156-159. DOI: https://www.doi.org/10.1016/S0301-2115(02)00100-8

Riccardi D, Brennan SC, and Chang W (2013). The extracellular calcium-sensing receptor, CaSR, in fetal development. Best Practice \& Research Clinical Endocrinology, 27: 443-453. DOI: https://www.doi.org/10.1016/j.beem.2013.02.010

Rosner JY, Gupta M, McGill M, Xue X, Chatterjee PK, Yoshida-Hay M, Robeson W, and Metz CN (2016). Magnesium deficiency during pregnancy in mice impairs placental size and function. Placenta, 39: 87-93. DOI: https://www.doi.org/10.1016/j.placenta.2016.01.009

Ruan Z, Zhang YG, Yin YL, Li TJ, Huang RL, Kim SW, Wu GY, and Deng ZY (2007). Dietary requirement of true digestible phosphorus and total calcium for growing pigs. Asian-Australasian Journal of Animal Sciences, 20(8): 1236-1242. DOI: https://www.doi.org/10.5713/ajas.2007.1236

Ruginosu E, Creangă Ş, Sofronie M, Mălăncuş R, Boghian V, and Solcan G (2011). The biochemical profile in cows with reproductive disorders. Cercetari Agronomice in Moldova, 44(2): 75-86. DOI: https://www.doi.org/10.2478/v10298-012-0035-4

Saliy MG, Tkachenko LV, Yakupova IH, and Polyakov VK (2013). The importance of iron deficiency in the formation of reproductive disorders in hypothalamic puberty dysfunction in adolescent girls. Astrahanskij medicinskij zhurnal, 8(4): 89-93. https://cyberleninka.ru/article/n/znacheniedefitsita-zheleza-v-formirovanii-reproduktivnyh-narusheniy-pri-gipotalamicheskoy-disfunktsii-pubertatnogo-perioda-u/viewer

Savinova AA, Semenchenko SV, and Falynskova NP (2015). Vitamins in livestock and veterinary medicine. Scientific magazine, Kontsep, pp. 3-56. Available at: https://elibrary.ru/item.asp?id=24018139

Scholl TO, Hediger ML, Schall JI, Fischer RL, and Khoo CS (1993). Low zinc intake during pregnancy: its association with preterm and very preterm delivery. American Journal of Epidemiology, 137(10): 1115-1124. DOI: https://www.doi.org/10.1093/oxfordjournals.aje.a116615

Serjakov IS, and Judina TA (2014). Reproductive qualities of sows when chromium is introduced into their diet. Razrabotka i vnedrenie novyh tehnologij poluchenija i pererabotki produkcii zhivotnovodstva. Troick: UGAVM, pp. 168-175. Available at: https://agris.fao.org/agrissearch/search.do?recordID=BY2012000945

Seyfi H, Farzaneh N, and Mohri M (2005). Relationships between fertility, serum calcium, and inorganic phosphorus in dairy cows. Iranian Journal of Veterinary Research, 6(2): 74-78. Available at: https://www.sid.ir/en/journal/ViewPaper.aspx?id=41053

Shatohin PP, Suprunenko KV, Karysheva LP, Derenchuk JI, and Krylevec' JV (2017). Korektsiya at the time of Vitamin A and zinc at the blood of the blood of the remaining trimester of foals for nutritional deficiencies. Visnyk Poltavs'koi' Derzhavnoi' Agrarnoi' Akademii', 3: 96-100. DOI: https://www.doi.org/10.31210/visnyk2017.03.21 
Sheela C, and Ajay S (2004). Role of nutrition in reproduction: A review. Intas Polivet, 5(2): 229-234. Available at: https://www.cabdirect.org/cabdirect/abstract/20053131305

Sidorkin V, Polutov D, and Komarov A (2007). The role of vitamins in the prevention of diseases of the reproductive system in cows. Molochnoe i Mjasnoe Skotovodstvo, 5: 31-32. Available at: https://elibrary.ru/item.asp?id=9538621

Siemons LJ, and Mahler CH (1987). Hypogonadotropic hypogonadism in hemochromatosis: recovery of reproductive function after iron depletion. The Journal of Clinical Endocrinology and Metabolism, 65(3): 585-587. DOI: https://www.doi.org/10.1210/jcem-65-3-585

Simkiss K (1961). Calcium metabolism and avian reproduction. Biological Reviews, 36(3): 321-359. DOI: https://www.doi.org/10.1111/j.1469185X.1961.tb01292.X

Skliarov PM, Fedorenko SJ, Naumenko SV, Onyshhenko OV, Pasternak AM, and Holda KO (2020a). Separate indices of homeostasis and the balance of the prooxidant-oxidant system in sheep for fetoplacental insufficiency. Ukrainian Journal of Ecology, 10(2): 440-448. DOI: https://www.doi.org/10.15421/2020_121

Skliarov PM, Fedorenko SY, Naumenko SV, Onischenko OV, and Holda KO (2020b). Retinol deficiency in animals: Etiopathogenesis and consequences. Regulatory Mechanisms in Biosystems, 11(2): 162-169. DOI: https://www.doi.org/10.15421/022024

Skljarov P (2017). Reproductive function in sheep and goats with Vitamin A deficiency. LAP LAMBERT Academic Publishing, p. 516. Available at: http://dspace.dsau.dp.ua/jspui/handle/123456789/709

Skljarov PM, and Koshevoj VP (2016). Complex preparations based on nanobiomaterials, prospects for use in reproduction of sheep and goats Naukovyj visnyk L'vivs'kogo nacional'nogo universytetu veterynarnoi' medycyny ta biotehnologij imeni S.Z. G'zhyc'kogo, 18(2): 162-165. Available at: http://nbuv.gov.ua/UJRN/nvlnuvmbvn_2016_18_2_35

Smith OB, and Akinbamijo OO (2000). Micronutrients and reproduction in farm animals. Animal Reproduction Science, 60: 549-560. DOI: https://www.doi.org/10.1016/s0378-4320(00)00114-7

Stoecker BJ (1990). Chromium: Present knowledge in nutrition. International life sciences institute nutrition foundation, Washington, DC, pp. $287-293$. Available at: https://ci.nii.ac.jp/naid/10011118264/

Strizhakov A, Davydov A, Lebedev V, Ignatko I, Makatsariya A, Mezhevitinova E, and Pshenichnikova T (2009). The biological role of magnesium in obstetrics and gynecology: Research data and clinical studies. Voprosy ginekologii, Akusherstva i Perinatologii, 3(8): 5-18. Available at: https://elibrary.ru/item.asp?id=12591288

Sun W, Chen L, Zhang W, Wang R, Goltzman D, and Miao D (2015). Active Vitamin D deficiency mediated by extracellular calcium and phosphorus results in male infertility in young mice. American Journal of Physiology-Endocrinology and Metabolism,308(1): 51-62. DOI: https://www.doi.org/10.1152/ajpendo.00076.2014

Tallam SK, Ealy AD, Bryan KA, and Wu Z (2005). Ovarian activity and reproductive performance of dairy cows fed different amounts of phosphorus. Journal of Dairy Science, 88(10): 3609-3618. DOI: https://www.doi.org/10.3168/jds.s0022-0302(05)73046-0

Thomas P (1993). Effects of cadmium on gonadotropin secretion from Atlantic croaker pituitaries incubated in vitro. Marine Environmental Research, 35(1-2): 141-145. DOI: https://www.doi.org/10.1016/0141-1136(93)90028-X

Truong JT, and Booth SL (2011). Emerging issues in Vitamin K research. Journal of Evidence - Based Complementary and Alternative Medicine, 16(1): 73-79. DOI: https://www.doi.org/10.1177/1533210110392953

Umahanov MA (2017). The main factors affecting the reproductive functions of cattle. Gornoe sel'skoe Hozjajstvo, 1: 148-152. Available at: https://elibrary.ru/item.asp?id=29025471

Ushkalov VA (2001). The use of sodium humate to restore reproductive function in cows after childbirth. Veterinarija. Referativnyj Zhurnal, 4: 11351135. Available at: https://elibrary.ru/item.asp?id=6568826

Vishnjakov AI, and Lebedev SV (2011). Features of the influence of cadmium on mineral metabolism and morphological state of the reproductive system of mammals and birds. Fundamental'nye issledovanija, 1(9): 135-138. Available at: https://www.fundamentalresearch.ru/ru/article/view?id=28110

Vizner Z (1976). Feeding and fertility of farm animals. Moskva, p. 160. Available at: https://it.2lib.org/d1/2831963/b22513

Weiss WP (1998). Requirements of fat-soluble vitamins for dairy cows: A review. Journal of Dairy Science, 81(9): 2493-2501. DOI: https://www.doi.org/10.3168/jds.s0022-0302(98)70141-9

Wirth JJ, and Mijal RS (2010). Adverse effects of low level heavy metal exposure on male reproductive function. Systems Biology in Reproductive Medicine, 56(2): 147-167. DOI: https://www.doi.org/10.3109/19396360903582216

Yasothai R (2014). Importance of minerals on reproduction in dairy cattle. International Journal of Science, Environment and Technology, 3(6): 20512057. Available at: https://www.ijset.net/journal/446.pdf

Zhai XW, Zhang YL, Qi Q, Bai Y, Chen XL, Jin LJ, Ma XG, Shu RZ, Yang ZJ, and Liu FJ (2013). Effects of molybdenum on sperm quality and testis oxidative stress. Systems Biology in Reproductive Medicine, 59(5): 251-255. DOI: https://www.doi.org/10.3109/19396368.2013.791347

Zhang YL, Liu FJ, Chen XL, Zhang ZQ, Shu RZ, Yu XL, Zhai XW, Jin LJ, Ma XG, Qi Q et al. (2013). Dual effects of molybdenum on mouse oocyte quality and ovarian oxidative stress. Systems Biology in Reproductive Medicine, 59(6): 312-318. DOI: https://www.doi.org/10.3109/19396368.2013.826296

Zhegalova IV, Chumakova ZV, and Jurasov VV (2018). Cadmium and male reproductive health. Mikrojelementy v Medicine, 19(1): 24-34. Available at: http://www.journal.microelements.ru/trace elements in medicine/2018 1/24 19(1) 2018.pdf 